\title{
DOES FAMILY SUPPORT PREVENT PREECLAMPSIA, AFTER CONTROLLING FOR AGE, PARITY, AND ANTENATAL VISIT? A NEW EVIDENCE FROM KEDIRI, EAST JAVA
}

\author{
Katmini',4), Bhisma Murti²), Tedjo Danudjo Oepomo3), \\ Sapja Anantanyu4) \\ ${ }^{1)}$ School of Health Sciences Bhakti Mulia, Kediri, East Java \\ 2) Masters Program of Public Health, Universitas Sebelas Maret \\ 3)Department of Obstetrics and Gynecology, Faculty of Medicine, \\ Universitas Sebelas Maret \\ 4)Doctoral Program in Community Development and Empowerment, \\ Universitas Sebelas Maret
}

\begin{abstract}
Background: Studies have shown that family is an important unit of support for every individual in dealing with stress. Women with high stress level prior to pregnancy and low support had the highest rate of gestation, infant complications, complications of pregnancy, and emotional disequilibrium. Individuals who receive more support from several sources experience different level of satisfaction. Little is known about the association between family support and the risk of preeclampsia in Indonesia. This study aimed to examine the association between family support and the risk of preeclampsia, after controlling for biologic and other social factor including age, parity, and antenatal visit.

Subjects and Method: This was a case control study conducted at Amelia Hospital, Kediri, East Java, from December 2017 to February 2018. A sample of 160 pregnant women was selected for this study by fixed disease sampling resulting in 40 women with preeclampsia and 120 women without preeclampsia. The dependent variable was pre-eclampsia. The independent variables were age, parity, ANC visit, and family support. The family support comprised financial, instrumental, emotional, and informational aspects. Data on preeclampsia was taken from medical record based on doctor's clinical examination and diagnosis. The data on other variables were measured by a set of questionnaire. The data were analyzed by a multiple logistic regression.

Results: The risk of preeclampsia decreased with age 20-35 years $(b=-0.88$; $95 \% \mathrm{CI}=-1.68$ to $-0.08 ; \mathrm{p}=0.031)$, multiparity $(\mathrm{b}=-0.96 ; 95 \% \mathrm{CI}=-1.79$ to -0.14 ; $\mathrm{p}=0.022)$, complete antenatal visit $(\mathrm{b}=-0.79 ; 95 \% \mathrm{CI}=-1.59$ to $0.01 ; \mathrm{p}=0.050)$, and strong family support $(b=-1.16 ; 95 \% \mathrm{CI}=-2.06$ to $-0.26 ; \mathrm{p}=0.011)$. Log likelihood $=-76.2$. Pseudo $\mathrm{R}^{2}=15 \cdot 3 \%$.
\end{abstract}

Conclusion: Family support has an important role to prevent preeclampsia, after controlling for age, parity, and antenatal visit.

Keywords: preeclampsia, age, parity, antenatal visit, family support

\section{Correspondence:}

Katmini. School of Health Sciences Bhakti Mulia, Kediri, East Java.

Mid-International Conference in Public Health, Best Western Premiere Hotel, Solo, Indonesia, 18-19 April 2018 | 217 https://doi.org/10.26911/mid.icph.2018.03.53 